\title{
Cadmium and copper accumulation and toxicity in the macroalga Gracilaria tenuistipitata
}

\author{
Xu Huang, Caihuan Ke, Wen-Xiong Wang* \\ State Key Laboratory for Marine Environmental Science, College of Oceanography and Environmental Science, \\ Xiamen University, Xiamen 361005, China
}

\begin{abstract}
The macroalga Gracilaria tenuistipitata is widely distributed in the coastal waters of southern China, and is extensively used as the main food source in abalone aquaculture. However, it also possesses a high ability to accumulate trace metals in its tissues. This study investigated the accumulation of cadmium $(\mathrm{Cd})$ and copper $(\mathrm{Cu})$ in this macroalga under various temperatures and salinities, and the subsequent influences on growth rate, lipid peroxidation, and total energy reserve. The accumulation of both $\mathrm{Cd}$ and $\mathrm{Cu}$ was enhanced with increasing temperature and decreasing salinity. The bioaccumulation factor of $\mathrm{Cu}$ was 10 times higher than that of $\mathrm{Cd}$. Changes in temperature, salinity and accumulated metals all affected the tested biomarkers to some extent. We demonstrated that growth rate, lipid peroxidation level and total energy reserve were all significantly correlated with the accumulated tissue $\mathrm{Cu}$ concentrations, suggesting that $\mathrm{Cu}$ accumulation in the tissue can be used as a proxy for measuring $\mathrm{Cu}$ toxicity in $\mathrm{G}$. tenuistipitata under various environmental conditions. In contrast, among the 3 toxic endpoints, only growth rate was inversely related to the $\mathrm{Cd}$ tissue concentrations. $\mathrm{Cu}$ exerted a greater toxic effect on $\mathrm{G}$. tenuistipitata than $\mathrm{Cd}$, largely due to its different toxicological mechanisms and biological accumulation potentials. $\mathrm{Cd}$ appeared to have no profound influence on the production of reactive oxygen species. A higher Cd accumulation at lower salinity did not cause a stronger growth inhibition as compared to $\mathrm{Cu}$. Given the commercial value of the macroalga as a main food source in abalone aquaculture, $\mathrm{Cu}$ contamination and high temperature should be avoided in the culture of G. tenuistipitata, because they can reduce its energy reserves.
\end{abstract}

KEY WORDS: Metal · Growth · Lipid peroxidation · Energy reserves · Gracilaria tenuistipitata Resale or republication not permitted without written consent of the publisher

\section{INTRODUCTION}

Industrialization is one of most important sources of metal pollution in the coastal regions of China. In 2008, the State Oceanic Administration of China declared that copper $(\mathrm{Cu})$ and cadmium $(\mathrm{Cd})$ are the main metal pollutants in coastal sediments, and that at several locations in Hainan Province (a tropical region), sediments were severely polluted with $\mathrm{Cd}$. The red seaweed Gracilaria tenuistipitata is widely distributed in the tropical and subtropical zones of China. Mariculture of $G$. tenuistipitata is a promising business, because this macroalga has been used as the major forage for culturing abalone Haliotis diversicolor, a marine gastropod with high commercial value. Indeed, a significant portion of $G$. tenuistipitata used as forage for abalone culture in China comes from Hainan Province, thus there is a great potential that this forage may be subjected to metal contamination. Huang et al. (2008) suggested that diet was the dominant pathway for $\mathrm{Ag}, \mathrm{Cd}$ and $\mathrm{Hg}$ accumulation in abalone, and metals can be transferred trophically from macroalgae to abalone. Huang et al. (2010) also found that feeding and growth in $H$. diversicolor was generally inhibited when exposed to metal-contaminated $G$. tenuistipitata or seawater. Therefore, there is a substantial need to understand metal accumulation in this macroalga.

Macroalgae are capable of accumulating trace metals in concentrations several thousand times higher than those in the surrounding seawater (Sanchez- 
Rodriguez et al. 2001, Muse et al. 2006). Field studies suggest that metal concentrations in seaweed are generally proportional to those in ambient water (Haritonidis \& Malea 1995, Sanchez-Rodriguez et al. 2001). Therefore, macroalgae are often used as biomonitors to assess marine metal pollution (Abdallah \& Abdallah 2008, Astorga-España et al. 2008). As an important primary producer, macroalgae also have a large capacity to take up inorganic nutrients. Coelho et al. (2005) speculated that with increasing eutrophication worldwide, macroalgae could become a remarkable pool of metals for herbivorous organisms because of their high potential for metal accumulation and high growth rate. Due to the importance of macroalgae as forage (Zemke-White \& Ohno 1999), their quality would impose direct and crucial influence on herbivorous marine animals. For example, adult feeding rates and juvenile survivorship in the amphipod Peramphithoe parmerong were reduced when feeding on $\mathrm{Cu}$-spiked macroalgae (Roberts et al. 2006).

In addition to addressing the harmful effects of metalcontaminated macroalgae on abalone aquaculture, the effect of metal pollution on the growth and photosynthesis of macroalgae themselves should be considered (Brown \& Newman 2003, Collén et al. 2003, Xia et al. 2004). However, such influences of metal contamination on macroalgae have been rarely studied, especially regarding the total energy reserve, derived from the sum of available energy from carbohydrate, protein and lipids. De Coen \& Janssen (1997) proposed to use cellular energy allocation (CEA) to assess the effects of toxic stress on the energy budget of tested organisms, as an alternative method to the conventional scope-forgrowth methodology. In food chemistry, carbohydrate, protein and lipids are the 3 most important components and parameters of nutritional values (Norziah \& Ching 2000). Thus, it is very likely that if specific environmental stressors can disturb the energy reserves of Gracilaria tenuistipitata, they can also influence the growth of abalone indirectly.

In the present study, we tested the accumulation of $\mathrm{Cd}$ and $\mathrm{Cu}$ in the macroalga Gracilaria tenuistipitata under various temperatures and salinities, and then measured the toxic responses of the macroalga for growth rate, lipid peroxidation and energy reserve. We compared the toxic responses to $\mathrm{Cd}$ and $\mathrm{Cu}$, given the potentially high concentrations of these metals in the Chinese coastal waters where this macroalga is grown. One hypothesis tested in this study was whether trace metal accumulation in the tissue could be used to interpret the different toxic responses of macroalgae grown under different temperatures and salinities. Thus, the correlation between the elevated metal concentrations in G. tenuistipitata and the corresponding toxic end points was examined.

\section{MATERIALS AND METHODS}

Macroalga. Samples of Gracilaria tenuistipitata were collected from an abalone farm in Dapeng Bay, Guangdong Province, China, in April 2009. The epiphytic particles of the seaweed were removed. The samples were then maintained in aerated aquaria with $0.22 \mu \mathrm{m}$ filtered seawater (33 psu), enriched with $160 \mu \mathrm{M} \mathrm{NaNO}{ }_{3}$ and $8 \mu \mathrm{M} \mathrm{NaH} \mathrm{PO}_{4}$. Temperature was maintained at $18^{\circ} \mathrm{C}$ and light illumination at $80 \mu \mathrm{mol}$ $\mathrm{E} \mathrm{m}^{-2} \mathrm{~s}^{-1}$ in a 14:10 h light:dark cycle.

Exposure. In all the metal exposure experiments, nutrients, light illumination and light:dark cycle were kept as described above. Temperature and salinity were set up as 2 factors and the whole experiment was divided into the 2 groups, 'temperature' and 'salinity'. In the temperature group, various temperatures $(18,23$ and $28^{\circ} \mathrm{C}$ ) were controlled in 3 environmental chambers, with salinity fixed at $33 \mathrm{psu}$. In the salinity group, various salinities $(20,26$ and $33 \mathrm{psu})$ were prepared with $0.22 \mu \mathrm{m}$ filtered seawater (33 psu) and Milli-Q water, and temperature was fixed at $18^{\circ} \mathrm{C}$. Despite the fact that Gracilaria tenuistipitata is considered an estuarine species, we conducted the temperature experiment at 33 psu, primarily because this was the salinity of the coastal waters at the time the macroalga samples were collected.

Before the metal exposure, we acclimatized the macroalga to the different temperatures and salinities. Branches of Gracilaria tenuistipitata with similar sizes were picked out from the aquarium. Three replicates were used for each treatment: each replicate consisted of 3 branches placed into a beaker containing $1 \mathrm{l}$ of $0.22 \mu \mathrm{m}$ filtered and nutrient-enriched seawater. The medium was adjusted to the target salinity and gently aerated at the different temperatures. The water was renewed every $2 \mathrm{~d}$. After $7 \mathrm{~d}$ of acclimatization, the fresh weights (FW) of all branches were measured after blotting dry with paper towels. The branches were then placed into beakers containing fresh medium under the same temperature and salinity conditions as used during acclimatization. The following day, $\mathrm{Cd}$ and $\mathrm{Cu}$ were added to the beakers separately. The nominal concentrations of $\mathrm{Cd}$ and $\mathrm{Cu}$ (both in $0.1 \mathrm{M} \mathrm{HCl}$, with a stock metal concentration of $1 \mathrm{mg}$ $\mathrm{ml}^{-1}$ ) spiked into the medium were 0 (without metal spike), 10, 50 and $200 \mathrm{\mu g} \mathrm{l}^{-1}$, respectively. The choice of these concentrations was based on both environmental relevance and the likely observable toxicological effects. Maximum concentrations of $\mathrm{Cd}$ and $\mathrm{Cu}$ in the coastal waters of China can reach up to 4 and $16 \mu \mathrm{g} \mathrm{l}^{-1}$, respectively (Wan et al. 2008, Dai et al. 2009). Our preliminary experiments showed that the highest concentration (200 $\mathrm{gg} \mathrm{l}^{-1}$ for both metals) employed in this study was not lethal to G. tenuistipitata, and in fact, 
such a high concentration was not uncommon in areas influenced by industrial effluents in China (a recent effluent spill in Fujian Province resulted in a $\mathrm{Cu}$ concentration of $>200 \mu \mathrm{g} \mathrm{Cu} \mathrm{l}^{-1}$ in river waters). $\mathrm{NaOH}$ (suprapure) was added to the seawater to maintain the $\mathrm{pH}$ at 8.0 because the spike metals were carried in $\mathrm{HCl}$ solution. The exposure experiment lasted for $2 \mathrm{wk}$. The medium was renewed every $2 \mathrm{~d}$ to maintain the metal and nutrient concentrations.

Relative growth rate and percentage of growth inhibition. At the end of the $2 \mathrm{wk}$ exposure, the FW of all macroalga branches were measured again after blotting dry with paper towels. The relative growth rate $\left(G_{\mathrm{r}}\right)$ of individual branches was calculated by the following equation:

$$
G_{\mathrm{r}}=\frac{\ln \left(w_{t} / w_{0}\right)}{t} \times 100
$$

where $w_{0}$ and $w_{t}$ are the fresh weight of a branch at the beginning and at time $t(\mathrm{~d})$, respectively. In addition, the percentage of growth rate inhibition when exposed to metals under different experimental conditions was compared with the control treatment $(0 \mu \mathrm{g} \mathrm{CD}$ or $\mathrm{CU})$, in order to analyze whether metal toxicity was influenced by temperature or salinity.

Metal concentrations in the macroalga. Branches of the macroalga (1 branch from each beaker) were put into pre-weighed glass tubes and dried at $80^{\circ} \mathrm{C}$ until they reached a constant weight. The dried tissues were weighed and digested with $70 \%$ nitric acid (Fisher Scientific) at room temperature for $12 \mathrm{~h}$ and at $80^{\circ} \mathrm{C}$ for $2 \mathrm{~h}$, and then heated at $110^{\circ} \mathrm{C}$ in an auto-regulated heating block until the tissues were digested thoroughly. At the same time, oyster tissue standard (1566a, US National Institute of Standards and Technology) was digested as a reference material. The digests were diluted with double-distilled water to an appropriate range of concentrations before they were quantified using a HITACHI Z-8100 polarized Zeeman Atomic Absorption Spectroscopy (AAS) system. The recovery of metals in the oyster standards was $>95 \%$. The metal concentrations in the macroalga branches were expressed as $\mu \mathrm{g} \mathrm{g}^{-1}$ dry weight.

Lipid peroxidation. Lipid peroxidation is an indicator of oxidative stress caused by metal exposure. The main by-product of lipid peroxidation is malondialdehyde (MDA), which is a thiobarbituric acid reactive (TBAR) compound. Branches of the macroalga were taken from each replicate and cut into small pieces. Approximately $0.5 \mathrm{~g}$ of the macroalga was then homogenized in $5 \mathrm{ml}$ of $10 \%$ trichloroacetic acid (TCA) with a mortar and pestle. The samples were centrifuged at $4000 \times g$ for $10 \mathrm{~min}$. Two $\mathrm{ml}$ of supernatant was then mixed with $2 \mathrm{ml}$ of $0.6 \%$ thiobarbituric acid (TBA) solution (or with $2 \mathrm{ml}$ Milli-Q water as control), incubated in a water-bath at $95^{\circ} \mathrm{C}$ for $30 \mathrm{~min}$, chilled, and centri- fuged at $4000 \times g$ for $10 \mathrm{~min}$. Absorbances (optical density, OD) were measured at 450, 532, and $600 \mathrm{~nm}$. MDA equivalents were calculated by the following equation (Cheung et al. 2006):

MDA $\left(\mu \mathrm{mol} \mathrm{l} \mathrm{l}^{-1}\right)=6.45 \times\left(\mathrm{OD}_{532}-\mathrm{OD}_{600}\right)-0.56 \times \mathrm{OD}_{450}$

$\operatorname{MDA}\left(\mu \mathrm{mol} \mathrm{gFW}{ }^{-1}\right)=\frac{\operatorname{MDA}\left(\mu \mathrm{mol} \mathrm{l} \mathrm{l}^{-1}\right) \times \text { Volume }(\mathrm{ml})}{\mathrm{FW}(\mathrm{g})}$

Energy reserves. The energy reserves in the macroalga were measured after $\mathrm{Cd}$ and $\mathrm{Cu}$ exposure. Branches of macroalga from each replicate were freeze-dried and ground into powder. The measurement of lipids was based on the methods described in Cheung et al. (2006). Samples ( 10 mg dry weight) were weighed with a Mettler Toledo balance, mixed

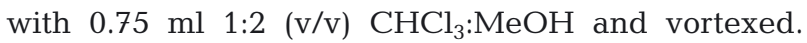
Then, $0.25 \mathrm{ml} \mathrm{CHCl}_{3}$ was added and vortexed. Finally, $0.45 \mathrm{ml}$ distilled water $\left(\mathrm{dH}_{2} \mathrm{O}\right)$ were added and vortexed. The samples were centrifuged at $8000 \times g$ for $10 \mathrm{~min}$ to produce a 2-phase system. Afterward, $50 \mu \mathrm{l}$ of the bottom liquid were removed, diluted with $\mathrm{dH}_{2} \mathrm{O}$ into $200 \mu \mathrm{l}$, then mixed with $1 \mathrm{ml}$ of concentrated $\mathrm{H}_{2} \mathrm{SO}_{4}$ and charred at $200^{\circ} \mathrm{C}$ for $15 \mathrm{~min}$. Absorbance was read at $370 \mathrm{~nm}$. Tripalmitin was used as the standard.

Anthrone-sulfuric acid colorimetric assay was used to determine the carbohydrate content (Roe 1955). Briefly, samples ( 10 mg dry weight) were weighed with a Mettler Toledo balance, and mixed with $5 \mathrm{ml}$ boiling water. The samples were incubated at $95^{\circ} \mathrm{C}$ in a shaker with water-bath for $10 \mathrm{~min}$ to extract carbohydrate, and then centrifuged. The supernatants were removed and diluted to $10 \mathrm{ml}$. One $\mathrm{ml}$ of aliquot was mixed with $4 \mathrm{ml}$ anthrone-sulfuric reagent $(1 \mathrm{ml}$ Milli-Q water as control), boiled for $10 \mathrm{~min}$, then cooled. Finally, the absorbance was determined at $620 \mathrm{~nm}$ using glucose as the standard.

A small quantity (2 to $5 \mathrm{mg}$ ) of freeze-dried sample was weighed and then determined for the total $\mathrm{N}$ content by an elemental CHNS analyzer. The total crude protein was then calculated from the total N, multiplying by 6.25 (Rebolloso Fuentes et al. 2000).

All experiments were performed in triplicate and all measurements were repeated 3 times. The energy reserves for the 3 components were calculated using factors based on the energy of combustion: $17500 \mathrm{~mJ}$ $\mathrm{mg}^{-1}$ glycogen, $24000 \mathrm{~mJ} \mathrm{mg}^{-1}$ protein, and $39500 \mathrm{~mJ}$ $\mathrm{mg}^{-1}$ lipid (Cheung et al. 2006). The available energy was calculated as the sum of carbohydrate, lipid and protein energy contents.

Statistical analysis. Since the temperature and salinity variation were not simultaneously involved in the experiment design, all the endpoints in this study 
were influenced by only 2 factors, metal concentration and temperature, or metal concentration and salinity. Therefore, 2-way ANOVA (SPSS 16.0) was first conducted to investigate whether these factors had significant influences on those endpoints. The interaction between the 2 factors was also considered. Tukey post hoc tests were used to make multiple comparisons between different levels of these factors. Regression analysis was then carried out to test for correlations between metal tissue concentration and the 3 toxic endpoints, growth rate, MDA and the total energy reserve. The significance level was set at $\mathrm{p}<0.05$.

\section{RESULTS}

\section{Metal accumulation after exposure}

Concentrations of $\mathrm{Cd}$ and $\mathrm{Cu}$ accumulated in the macroalga Gracilaria tenuistipitata after 2 wk of exposure at different temperatures and salinities are shown in Fig. 1. Statistical analysis indicated that in the temperature group, both temperature and seawater $\mathrm{Cd}$ concentration significantly influenced $\mathrm{Cd}$ accumulation in the tissues $(\mathrm{p}<0.001)$. There was also a significant interaction between temperature and seawater $\mathrm{Cd}$ concentration. Tissue $\mathrm{Cd}$ concentrations increased significantly when the seawater Cd level was elevated ( $\mathrm{p}<0.05$ ), while $\mathrm{Cd}$ accumulation at 23 and $28^{\circ} \mathrm{C}$ was 2.64 and 3.11 times higher, respectively, than at $18^{\circ} \mathrm{C}$ on exposure to

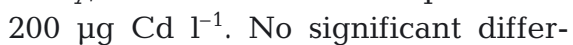
ence was observed between the 23 and $28^{\circ} \mathrm{C}$ treatments. In the salinity group, both salinity and $\mathrm{Cd}$ concentration as well as their interaction significantly influenced $\mathrm{Cd}$ accumulation ( $\mathrm{p}<0.05)$. Cd accumulation was significantly higher at 20 psu than at 26 and 33 psu ( $p<0.05$ ); no significant difference was observed between the 26 and 33 psu treatments.

The accumulation of $\mathrm{Cu}$ was also significantly influenced by seawater $\mathrm{Cu}$ concentration, temperature, and their interaction ( $p<0.05)$. Cu accumulation at 23 and $28^{\circ} \mathrm{C}$ was 1.36 and 1.95 times higher, respectively, than at

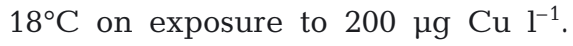
Likewise, $\mathrm{Cu}$ concentration, salinity, and their interaction significantly influenced $\mathrm{Cu}$ accumulation $(\mathrm{p}<$ 0.001). At $200 \mu \mathrm{g} \mathrm{Cu} \mathrm{l}{ }^{-1}, \mathrm{Cu}$ accumulation at 20 psu was 1.96 and 1.54 times higher at than 26 and 33 psu, respectively. $\mathrm{Cu}$ accumulation was about 10 times higher than that of $\mathrm{Cd}$ at comparable exposure concentrations. With increasing exposure concentration, the rate of $\mathrm{Cd}$ uptake slowed, but the rate of $\mathrm{Cu}$ uptake was maintained.

\section{Relative growth rate}

Growth rates in Gracilaria tenuistipitata were generally reduced upon exposure to $\mathrm{Cd}$ and $\mathrm{Cu}$ in all treatments (Fig. 2). Temperature (or salinity), Cd (or $\mathrm{Cu}$ ) concentration, as well as their interaction, significantly affected the growth rate $(\mathrm{p}<0.05)$ (Table 1$)$. For Cd exposure, in general, the growth rate was significantly lower at $28^{\circ} \mathrm{C}$ than at 18 and $23^{\circ} \mathrm{C}(\mathrm{p}<0.001)$, and significantly higher at 20 and 26 psu than at 33 psu (p < 0.001). For $\mathrm{Cu}$ exposure, the growth rate at $28^{\circ} \mathrm{C}$ was significantly lower than at 18 and $23^{\circ} \mathrm{C}(\mathrm{p}<0.001)$, and generally higher at $26 \mathrm{psu}$ than at 20 and $33 \mathrm{psu}$.

The extent of growth inhibition was different among the treatments (Table 2). The growth rates were

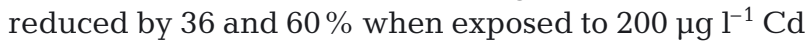
and $\mathrm{Cu}$, respectively, at $18^{\circ} \mathrm{C}$ and of $33 \mathrm{psu}$. At a higher temperature, the percentage of growth rate inhibition increased for both $\mathrm{Cd}$ and $\mathrm{Cu}$ exposure. However, macroalgae exposed to the 2 metals responded differently to a decrease in salinity; $\mathrm{Cd}$ and $\mathrm{Cu}$ accumulation was enhanced (Fig. 1), and growth rate inhibition for Cd exposure was reduced from 36 to $14 \%$.

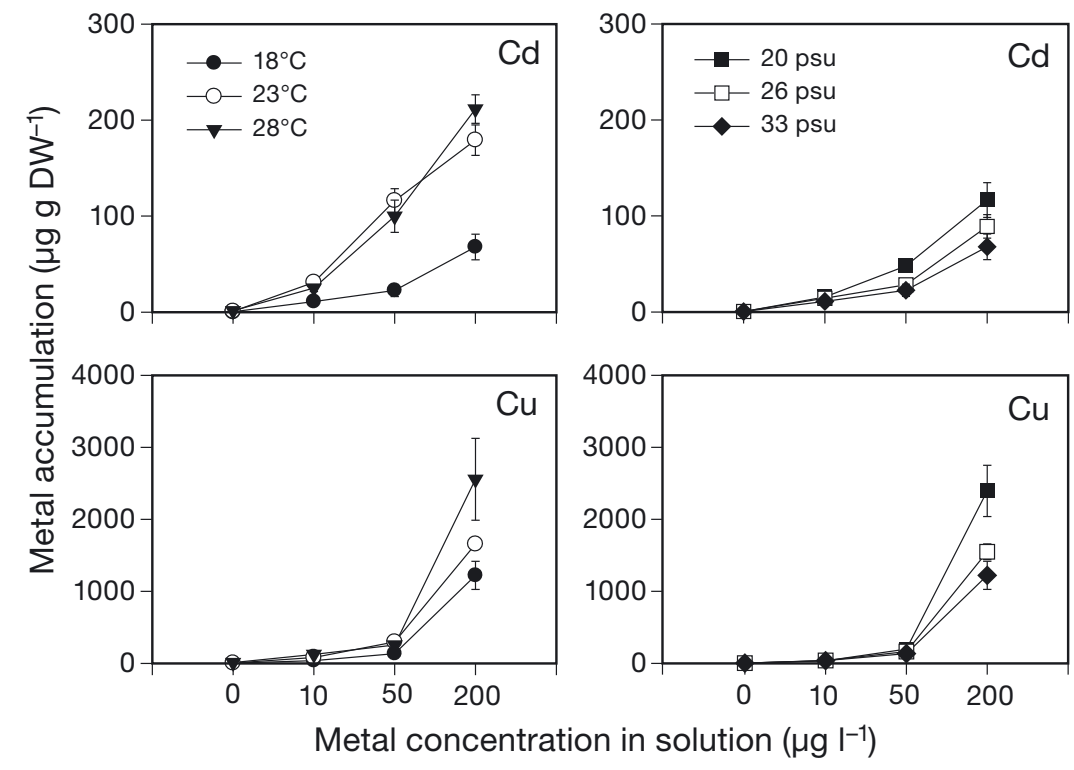

Fig. 1. Gracilaria tenuistipitata. Mean $\pm \mathrm{SD}(\mathrm{n}=3) \mathrm{Cd}$ and $\mathrm{Cu}$ tissue concentrations after 2 wk of exposure to increasing metal concentrations in solution under various temperatures (left panels, salinity fixed at $33 \mathrm{psu}$ ) and salinities (right panels, temperature fixed at $18^{\circ} \mathrm{C}$ ) 


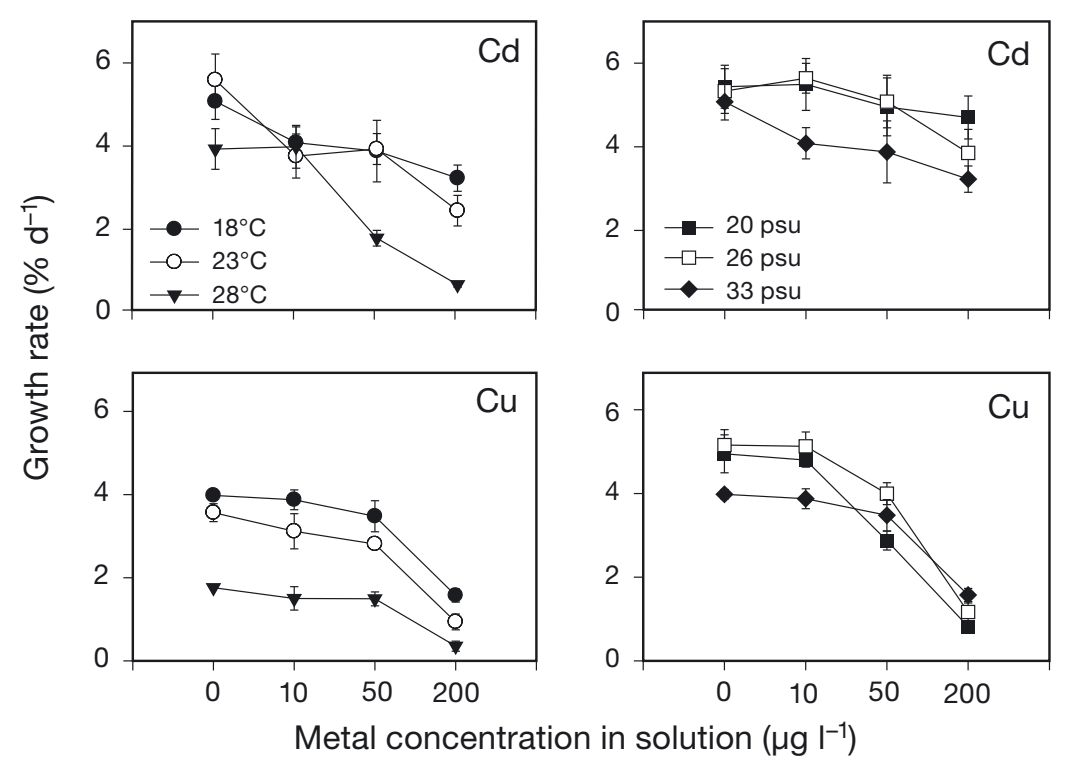

Fig. 2. Gracilaria tenuistipitata. Mean $\pm \mathrm{SD}(\mathrm{n}=3 \times 3)$ daily growth rates during 2 wk of exposure to various concentrations of $\mathrm{Cd}$ or $\mathrm{Cu}$ under various temperatures (left panels, salinity fixed at $33 \mathrm{psu}$ ) and salinities (right panels, temperature fixed at $18^{\circ} \mathrm{C}$ )

Table 1. Gracilaria tenuistipitata. Significance of the influences of temperature $(\mathrm{T})$, salinity $(\mathrm{S})$, and metal concentration (C) on growth, malondialdehyde (MDA; by-product of lipid peroxidation) level, and energy reserves analyzed by 2 -way ANOVA. Blank entries indicate that the result was non-significant. ${ }^{*} \mathrm{p}<0.05,{ }^{* *} \mathrm{p}<0.01$

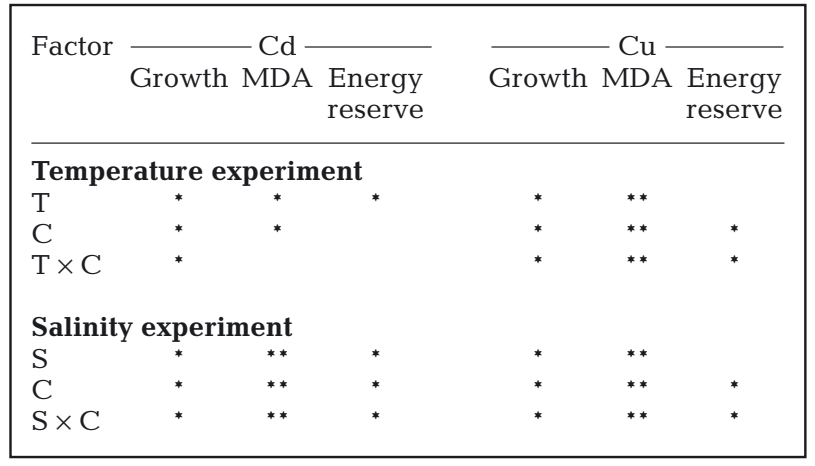

Table 2. Gracilaria tenuistipitata. Growth rate inhibition (\%) when exposed to $200 \mu \mathrm{g} \mathrm{l}^{-1} \mathrm{Cd}$ and $\mathrm{Cu}$, as compared to growth without metal exposure, under various environmental conditions

\begin{tabular}{|c|c|c|}
\hline \multirow{2}{*}{ Treatment } & \multicolumn{2}{|c|}{ Growth rate inhibition (\%) } \\
\hline & Cd exposure & $\mathrm{Cu}$ exposure \\
\hline $18^{\circ} \mathrm{C}, 33 \mathrm{psu}$ & 36 & 60 \\
\hline $23^{\circ} \mathrm{C}, 33 \mathrm{psu}$ & 56 & 74 \\
\hline $28^{\circ} \mathrm{C}, 33 \mathrm{psu}$ & 83 & 80 \\
\hline $18^{\circ} \mathrm{C}, 36 \mathrm{psu}$ & 28 & 77 \\
\hline $18^{\circ} \mathrm{C}, 20 \mathrm{psu}$ & 14 & 83 \\
\hline
\end{tabular}

\section{Lipid peroxidation}

Concentrations of lipid peroxidation product (MDA) in Gracilaria tenuistipitata are shown in Fig. 3. Cd concentration and temperature (but not their interaction) had a significant influence on MDA levels ( $p<0.05$ ) (Table 1), while Cd concentration, salinity, and their interaction all had a significant influence $(p<0.001)$. However, multiple comparisons suggested that the influence of $\mathrm{Cd}$ concentration on MDA was not dose-dependent. Only the MDA content at $10 \mu \mathrm{g} \mathrm{Cd}{ }^{-1}$ was significantly lower than that at

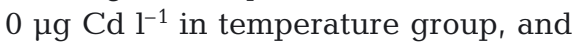
only the MDA content at $10 \mu \mathrm{g} \mathrm{Cd} \mathrm{l^{-1 }}$ was significantly lower than those at the other 3 concentrations in the salinity group ( $\mathrm{p}<0.05)$. In addition, the MDA contents were highest at $28^{\circ} \mathrm{C}$ and lowest at $23^{\circ} \mathrm{C}$ in the temperature group, whereas they were highest at 33 psu and the lowest at 26 psu in the salinity group. For the $\mathrm{Cu}$ experiment, $\mathrm{Cu}$ concentration, temperature (or salinity) and their interaction significantly affected MDA production $(\mathrm{p}<0.001)$. Multiple comparisons showed that MDA concentrations increased significantly with increasing $\mathrm{Cu}$ concentration ( $\mathrm{p}<0.001$ ). The MDA contents increased 1.55 to 1.75 -fold when $\mathrm{Cu}$ spike concentration was elevated from 0 to $200 \mu \mathrm{g}$ $\mathrm{Cu} \mathrm{l}^{-1}$. In addition, the MDA contents were $28^{\circ} \mathrm{C}>$ $18^{\circ} \mathrm{C}>23^{\circ} \mathrm{C}$, and $26 \mathrm{psu}=33 \mathrm{psu}>20 \mathrm{psu}$.

\section{Energy reserves}

Total energy reserves (the sum of available energy from carbohydrate, protein and lipids) in the macroalga are presented in Fig. 4. Only temperature (not Cd concentration) had a significant influence on total energy reserves in the temperature group $(p<0.05$, Table 1). In the salinity group, salinity, Cd concentration and their interaction had a significant influence on energy reserves $(p<0.05)$. Multiple comparisons suggested that the energy reserves decreased with increasing temperature $(\mathrm{p}<0.001)$, and were higher at 20 psu and 26 psu than at 33 psu. For $\mathrm{Cu}$ exposure, $\mathrm{Cu}$ concentration (not temperature or salinity) and their interaction had significant influence on total energy reserves $(p<0.05)$. Multiple comparisons also revealed that the total energy reserves were significantly reduced with higher $\mathrm{Cu}$ concentration in both the temperature and salinity groups. The energy reserves de- 


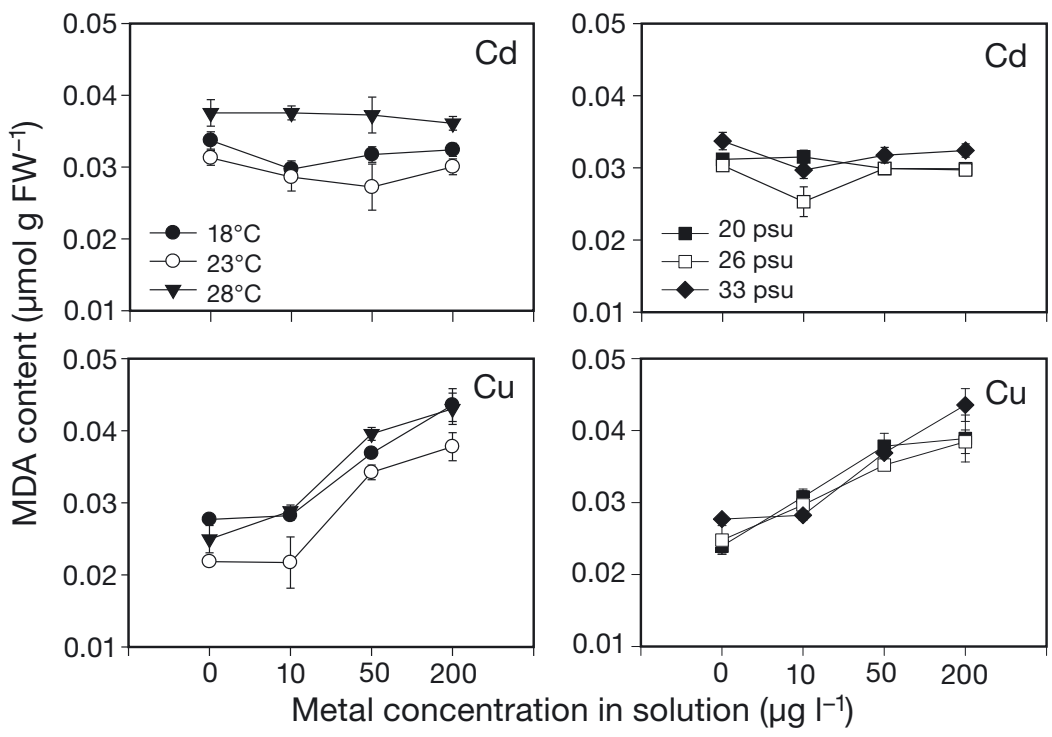

Fig. 3. Gracilaria tenuistipitata. Mean $\pm \mathrm{SD}(\mathrm{n}=3)$ malondialdehyde (MDA; byproduct of lipid peroxidation) contents after 2 wk of exposure to various concentrations of $\mathrm{Cd}$ or $\mathrm{Cu}$ under various temperatures (left panels, salinity fixed at $33 \mathrm{psu}$ ) and salinities (right panels, temperature fixed at $18^{\circ} \mathrm{C}$ )

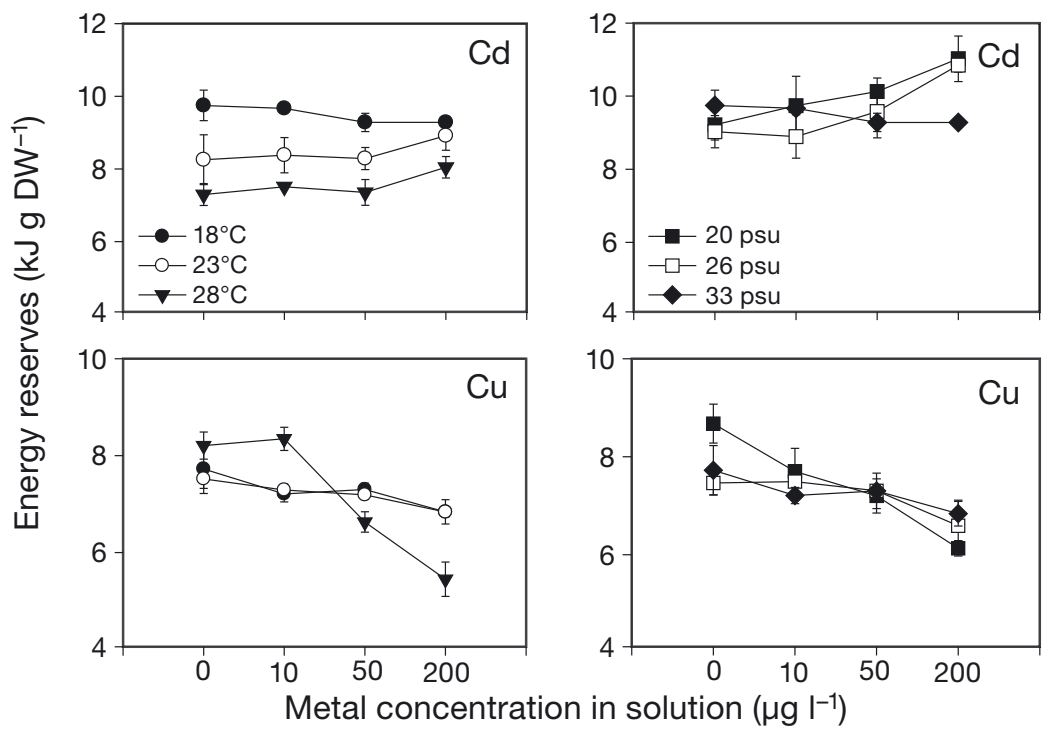

Fig. 4. Gracilaria tenuistipitata. Mean $\pm \mathrm{SD}(\mathrm{n}=3)$ energy reserves in G. tenuistipitata after 2 wk of exposure to various concentrations of $\mathrm{Cd}$ or $\mathrm{Cu}$ under various temperaturs (left panels, salinity fixed at $33 \mathrm{psu}$ ) and salinities (right panels, temperature fixed at $18^{\circ} \mathrm{C}$ )

creased by 34 and $30 \%$, respectively, at $28^{\circ} \mathrm{C}+33$ psu and $18^{\circ} \mathrm{C}+20$ psu when the $\mathrm{Cu}$ spike concentration increased.

\section{Correlation analysis}

The accumulated $\mathrm{Cd}$ and $\mathrm{Cu}$ concentrations measured in Gracilaria tenuistipitata varied greatly be- cause of the different exposure concentrations, temperatures and salinities. We further analyzed the relationships between the accumulated metal concentrations in the macroalga and the 3 toxic endpoints (growth, lipid peroxidation and total energy reserve). The results showed that in the $\mathrm{Cd}$ treatments, growth rates were significantly correlated with the tissue concentrations of $\mathrm{Cd}$ (in a linear function) (Fig. 5, left panels), whereas the MDA contents and energy reserves were not related to the tissue $\mathrm{Cd}$ concentrations. In the $\mathrm{Cu}$ treatments, all 3 endpoints were significantly correlated with the accumulated $\mathrm{Cu}$ concentrations (Fig. 5, right panels). Non-linear fit was used for $\mathrm{Cu}$, mainly because the pattern of $\mathrm{Cu}$ accumulation was an exponential one (Fig. 1).

\section{DISCUSSION}

\section{Influences of salinity and temperature on metal accumulation}

The patterns of $\mathrm{Cd}$ and $\mathrm{Cu}$ accumulation were strikingly different in both the temperature and salinity experiments. Munda (1979) found that Zn uptake in Fucus virsoides and Enteromorpha prolifera was temperaturedependent. In the present study, the $\mathrm{Cd}$ and $\mathrm{Cu}$ concentrations in Gracilaria tenuistipitata increased by 2.6 to 3.1 and 1.4 to 2.0 times, respectively, when the temperature rose from 18 to $28^{\circ} \mathrm{C}$. Fritioff et al. (2005) also demonstrated that concentrations of accumulated $\mathrm{Cu}, \mathrm{Zn}$ and $\mathrm{Cd}$ in 2 submersed plant species, Elodea canadensis (Michx.) and Potamogeton natans (L.), were influenced by temperature. An elevated temperature can enhance the molecular heat motion and modify the membrane lipid composition and permeability (Lynch \& Steponkus 1987), thus increasing the uptake of ions or other small molecules. The sensitivity of a marine diatom Thalassiosira nordenskioeldii to $\mathrm{Cd}$ toxicity also increased with increasing temperature, probably because Cd could enter the cell easily when the membrane composition and permeability were changed (Wang \& Wang 2008). 

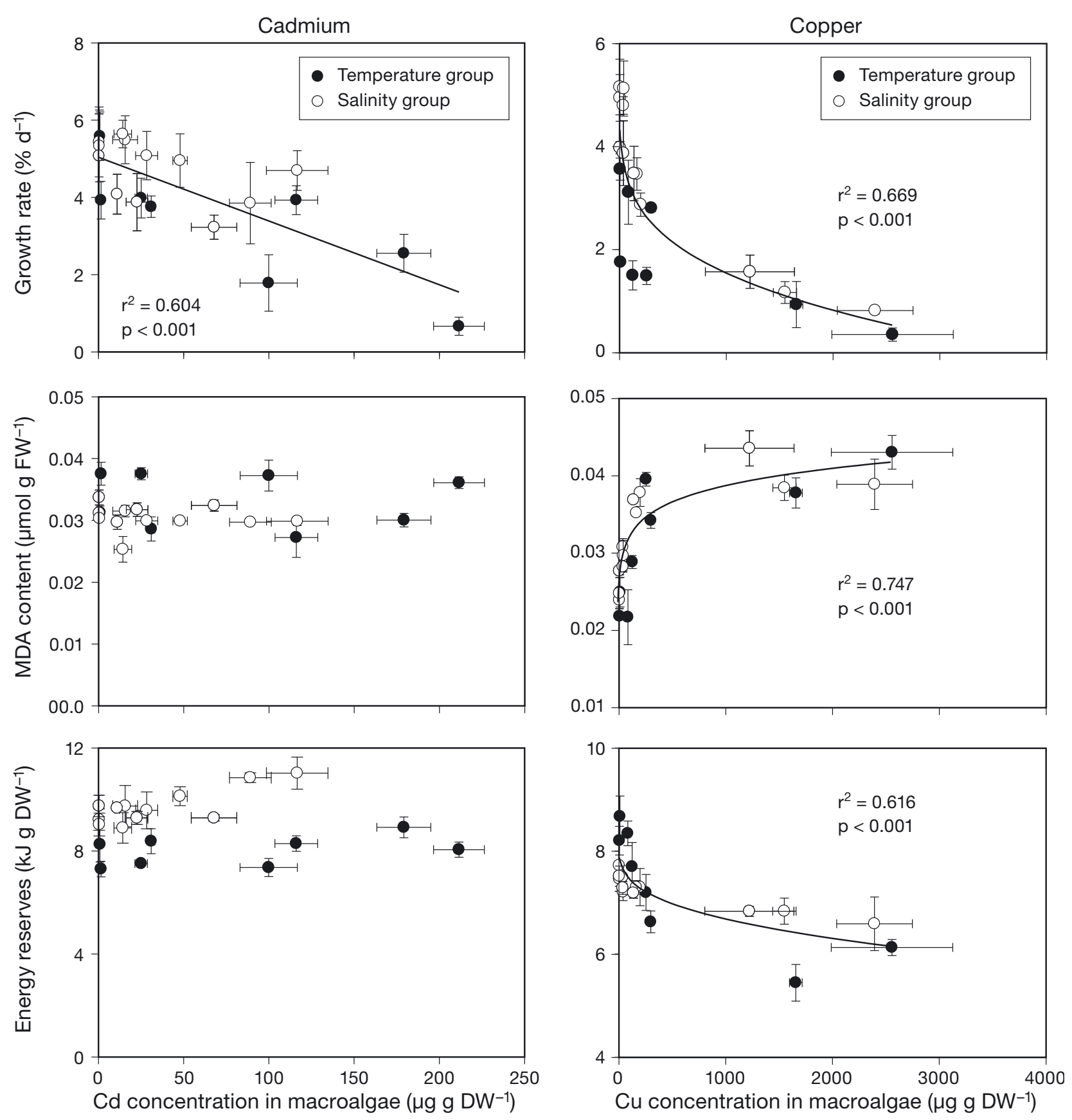

Fig. 5. Gracilaria tenuistipitata. Correlations between accumulated Cd (left panels) and Cu (right panels) tissue concentrations and 3 physiological responses (growth, MDA and available energy) in both temperature and salinity experiments. Values are mean $\pm \operatorname{SD}(n=3)$

The bioavailability of metals is greatly dependent on salinity. In the present study, the accumulated $\mathrm{Cd}$ and $\mathrm{Cu}$ concentrations in Gracilaria tenuistipitata were higher at a lower salinity; similar results have been documented in many previous studies. Wang \& Dei (1999) found that the uptake of Cd in Ulva lactuca and G. blodgettii was enhanced 1.9- to 2.0-fold with a decrease in salinity from 28 to 10 psu. Metal accumula- tion is controlled by the free ion concentration (reviewed by Campbell 1995). Generally, with an increase in salinity, more metal ions may be complexed with $\mathrm{Cl}^{-}$or other anions, resulting in a lower free ion concentration and, thus, a lower bioavailability. For example, the free $\mathrm{Cd}^{2+}$ accounted for 20,8 and $4.5 \%$ of the total $\mathrm{Cd}$ at a salinity of 5, 15 and $25 \mathrm{psu}$, respectively (Hall et al. 1995). 


\section{Physiological responses to $\mathrm{Cd}$ and $\mathrm{Cu}$}

Growth in organisms appear to be sensitive to a wide range of stressors, e.g. temperature, salinity, and metals, therefore it has been frequently used as an indicator to reflect the physiological acclimatization to environmental stressors (Weinberger et al. 2008). Gracilaria tenuistipitata can grow over a wide range of temperatures and salinities (Wu et al. 1994, Raikar et al. 2001). The optimal conditions for the growth of this macroalga were $22.5^{\circ} \mathrm{C}$ and 21 psu (op. cit.). In this study, we also found that temperatures of 18 to $23^{\circ} \mathrm{C}$ and salinities of 20 to 26 psu were optimal for the growth of $G$. tenuistipitata. However, the percentages of growth inhibition by metal exposure were somewhat complicated to interpret. Generally, growth was inhibited by $\mathrm{Cu}$ to a greater extent than by $\mathrm{Cd}$, partially because of their different accumulation levels. In the $\mathrm{Cu}$ treatments, the percentages of growth rate inhibition were consistent with their accumulated tissue $\mathrm{Cu}$ concentrations, whereas for $\mathrm{Cd}$ in the salinity group, the percentages of growth rate inhibition were inconsistent with the accumulated tissue $\mathrm{Cd}$ concentrations. One possible explanation is that a lower salinity was beneficial for the growth of $G$. tenuistipitata, thus alleviating the toxicity of $\mathrm{Cd}$, but the toxicity of $\mathrm{Cu}$ was too strong to overcome. Therefore, despite the growth rates of $G$. tenuistipitata being correlated to both $\mathrm{Cd}$ and $\mathrm{Cu}$ accumulation, the influence of accumulated $\mathrm{Cd}$ on macroalgal growth was relatively weaker than that of $\mathrm{Cu}$, consistent with previous studies (Collén et al. 2003, Xia et al. 2004). For example, the growth rate of $G$. lemaneiformis decreased by $7 \%$ when exposed for $4 \mathrm{~d}$ to $50 \mu \mathrm{M} \mathrm{Cd}$, whereas it decreased by $71.2 \%$ when exposed to $10 \mu \mathrm{M} \mathrm{Cu}$ (Xia et al. 2004).

The toxicity of metals may be in part related to the production of reactive oxygen species (ROS). An increase in lipid peroxidation by-product, MDA, is usually used as an indicator of oxidative stress. $\mathrm{Cu}$ is a transition metal involved in the Fenton reaction, which is a possible source of hydroxyl radicals; however, $\mathrm{Cd}$ is unable to participate in redox reaction. Therefore, Cd cannot induce hydroxyl radicals, which are theoretically the most reactive. However, Cd can promote the pro-oxidant status via reduction of the glutathione (GSH) pool, and bind the sites of essential elements ( $\mathrm{Ca}$ and $\mathrm{Zn}$ ), thus leading to the induction of hydroperoxides and superoxide anions. Collén et al. (2003) reported that $\mathrm{Cu}$ exposure was able to induce a greater extent of lipid peroxidation than $\mathrm{Cd}$ exposure. Similarly, in the present study, the MDA content was greatly elevated with increasing $\mathrm{Cu}$ concentration, but was little influenced by $\mathrm{Cd}$ exposure. Thus, the MDA content of Gracilaria tenuistipitata was only correlated with the $\mathrm{Cu}$ tissue burden. In addition, environmental changes such as temperature and salinity can also cause cellular damage and induce oxidative stress (Wang et al. 2009, Yang et al. 2009). In the present study, both temperature and salinity significantly affected the MDA levels in both the $\mathrm{Cd}$ and $\mathrm{Cu}$ experiments.

Recently, energy reserves, including available energy from proteins, carbohydrate and lipids, have been used as biomarkers to assess the effects of toxic stresses. Voets et al. (2006) demonstrated that total energy reserve was useful to monitor the impact of micropollutants, including trace metals and several organic compounds, because it gave a valuable indication of the physiological condition of zebra mussels Dreissena polymorpha. There has been no study on the effect of micropollutants on the energy reserves of aquatic plants. In the present study, the total energy reserves of Gracilaria tenuistipitata were gradually reduced with increasing $\mathrm{Cu}$ exposure concentration, whereas there was no obvious adverse effect of increasing $\mathrm{Cd}$ exposure. Our results suggest that, similar to lipid peroxidation, the level of energy reserves may be metaldependent. Elevated temperature also reduced the energy reserves of $G$. tenuistipitata in the Cd experiment and at high $\mathrm{Cu}$ exposure concentration. In the presence of $\mathrm{Cd}$, a low salinity was beneficial for the growth of G. tenuistipitata, thus leading to a higher energy reserve despite the higher $\mathrm{Cd}$ accumulation. The nutritional value of macroalgae is generally evaluated by determining the chemical composition, including fibre, ash, protein, carbohydrate, lipids and microelements. The energy of herbivorous and predatory animals usually comes from proteins, carbohydrate and lipids in the food. Therefore, the reduction of energy reserves in G. tenuistipitata would impact on the growth of herbivorous organisms such as abalone. Based on our measurements of the total energy reserve, Cu contamination and high temperature should be avoided in mariculture of $G$. tenuistipitata and abalone.

The toxicological mechanisms should be taken into consideration when explaining the different responses of Gracilaria tenuistipitata to $\mathrm{Cd}$ and $\mathrm{Cu}$. Excessive ROS are harmful because of their reaction with lipids, proteins and other cellular compounds, giving rise to oxidative stresses such as lipid peroxidation and protein carbonyls (Parvez \& Raisuddin 2005). Based on the MDA results, we conclude that $\mathrm{Cu}$ exposure induced a stronger oxidative stress than $\mathrm{Cd}$ exposure. Thus, the total energy reserve was reduced to a larger extent by the elevation of $\mathrm{Cu}$ accumulation than by that of $\mathrm{Cd}$, mainly due to the damage to lipids and proteins. Correlation analysis also implied that this macroalga can cope with the adverse effects of $\mathrm{Cd}$ accumulation to some degree. 
In contrast to $\mathrm{Cd}$, significant correlations were found between the accumulated $\mathrm{Cu}$ concentrations and the 3 indicators, suggesting that $\mathrm{Cu}$ tissue concentration was a good indicator of $\mathrm{Cu}$ toxicity. The considerable difference in the bioaccumulation of $\mathrm{Cd}$ and $\mathrm{Cu}$ by the macroalga was also responsible for the different toxic effects of $\mathrm{Cd}$ and $\mathrm{Cu}$. The calculated bioconcentration factor of $\mathrm{Cu}$ was 10 times higher than that of $\mathrm{Cd}$ in this study. In previous studies quantifying the physiological responses of seaweeds to $\mathrm{Cd}$ and $\mathrm{Cu}$ exposure, the actual metal accumulation in the tissues was generally not simultaneously quantified (Collén et al. 2003, Xia et al. 2004). Recently, Baumann et al. (2009) indicated that in 7 different marine macroalgae, metals were generally accumulated in the order of $\mathrm{Cu}>\mathrm{Pb}>\mathrm{Zn}>\mathrm{Cr}>\mathrm{Cd}$, and that $\mathrm{Cu}$ accumulation in these seaweeds was several times higher than $\mathrm{Cd}$ accumulation at the same exposure concentrations. Cd accumulation by Ulva intestinalis was regulated at higher exposed concentrations, whereas $\mathrm{Cu}$ accumulation was not regulated (Baumann et al. 2009). This phenomenon also occurred in the present study. Therefore, the different toxicological mechanisms and bioaccumulation potentials may both account for the different responses of the macroalga to $\mathrm{Cd}$ and $\mathrm{Cu}$ in the present study. It would also be interesting to understand the cellular mechanisms underlying the major difference in the bioaccumulation potentials of $\mathrm{Cd}$ and $\mathrm{Cu}$ in this macroalga.

To conclude, Gracilaria tenuistipitata favored relatively low temperature and low salinity based on its physiological responses. Growth rates, lipid peroxidation levels and energy reserves were significantly correlated with the accumulated $\mathrm{Cu}$ concentrations, whereas only the growth rates were inversely related to the $\mathrm{Cd}$ tissue concentrations. $\mathrm{Cd}$ appeared to have no profound influence via production of ROS. It was clear that $\mathrm{Cu}$ could exert a greater toxic effect on $G$. tenuistipitata than $\mathrm{Cd}$, largely due to the different toxicological mechanisms and biological accumulation potentials. Given the impacts on the nutritional values, $\mathrm{Cu}$ contamination and high temperature should be avoided in the culture of $G$. tenuistipitata, because they can reduce the energy reserves and may, thus, influence the production of abalone mariculture.

Acknowledgements. We gratefully acknowledge the anonymous reviewers for their constructive comments on this work. This work was supported by a grant from NSFC (40976067) and the Chang Jiang Chair Program (to W.X.W.), and an international collaborative project ('111' Program, project no. B07034).

\section{LITERATURE CITED}

Abdallah MAM, Abdallah AMA (2008) Biomonitoring study of heavy metals in biota and sediments in the South Eastern coast of Mediterranean sea, Egypt. Environ Monit Assess 146:139-145
Astorga-España MS, Calisto-Ulloa NC, Guerrero S (2008) Baseline concentrations of trace metals in macroalgae from the Strait of Magellan, Chile. Bull Environ Contam Toxicol 80:97-101

Baumann HA, Morrison L, Stengel DB (2009) Metal accumulation and toxicity measured by PAM - chlorophyll fluorescence in seven species of marine macroalgae. Ecotoxicol Environ Saf 72:1063-1075

Brown MT, Newman JE (2003) Physiological responses of Gracilariopsis longissima (S.G. Gmelin) Steentoft, L. M. Irvine and Farnham (Rhodophyceae) to sub-lethal copper concentrations. Aquat Toxicol 64:201-213

Campbell PGC (1995) Interactions between trace metals and aquatic organisms: a critique of the free-ion activity model. In: Tessier A, Turner DR (eds) Metal speciation and bioavailability in aquatic systems. Wiley, New York, NY, p 45-102

Cheung MS, Fok EM, Ng TY, Yen YF, Wang WX (2006) Subcellular cadmium distribution, accumulation, and toxicity in a predatory gastropod, Thais clavigera, fed different prey. Environ Toxicol Chem 25:174-181

Coelho JP, Pereira ME, Duarte A, Pardal MA (2005) Macroalgae response to a mercury contamination gradient in a temperate coastal lagoon (Ria de Aveiro, Portugal). Estuar Coast Shelf Sci 65:492-500

Collén J, Pinto E, Pedersén M, Colepicolo P (2003) Induction of oxidative stress in the red macroalga Gracilaria tenuistipitata by pollutant metals. Arch Environ Contam Toxicol 45:337-342

> Dai M, Peng S, Xu J, Liu C, Jin X, Zhan S (2009) Decennary variations of dissolved heavy metals in seawater of Bohai Bay, North China. Bull Environ Contam Toxicol 83:907-912

De Coen WM, Janssen CR (1997) The use of biomarkers in Daphnia magna toxicity testing. IV. Cellular energy allocation: a new methodology to assess the energy budget of toxicant-stressed Daphnia populations. J Aquat Ecosyst Stress Recovery 6:43-55

- Fritioff A, Kautsky L, Greger M (2005) Influence of temperature and salinity on heavy metal uptake by submersed plants. Environ Pollut 133:265-274

> Hall LW, Ziegenfuss MC, Anderson RD, Lewis BL (1995) The effect of salinity on the acute toxicity of total and free cadmium to a Chesapeake Bay copepod and fish. Mar Pollut Bull 30:376-384

> Haritonidis S, Malea P (1995) Seasonal and local variation of $\mathrm{Cr}, \mathrm{Ni}$ and Co concentrations in Ulva rigida C. Agardh and Enteromorpha linza (Linnaeus) from Thermaikos Gulf, Greece. Environ Pollut 89:319-327

Huang X, Ke C, Wang WX (2008) Bioaccumulation of silver, cadmium and mercury in the abalone Haliotis diversicolor from water and food sources. Aquaculture 283:194-202

> Huang X, Guo F, Ke C, Wang WX (2010) Responses of abalone Haliotis diversicolor to sublethal exposure of waterborne and dietary silver and cadmium. Ecotoxicol Environ Safety 73:1130-1137

Lynch DV, Steponkus PL (1987) Plasma membrane lipid alterations associated with cold acclimation of winter rye seedlings (Secale cereale L. cv Puma). Plant Physiol 83: 761-767

Munda IM (1979) Temperature dependence of zinc uptake in Fucus virsoides (Don.) J. Ag. and Enteromorpha prolifera (O. F. Müll.) J. Ag. from the Adriatic Sea. Bot Mar 22: 149-152

> Muse JO, Carducci CN, Stripeikis JD, Tudino MB, Fernández FM (2006) A link between lead and cadmium kinetic speciation in seawater and accumulation by the green alga Ulva lactuca. Environ Pollut 141:126-130 
Norziah MH, Ching CY (2000) Nutritional composition of edible seaweed Gracilaria changgi. Food Chem 68:69-76

Parvez S, Raisuddin S (2005) Protein carbonyls: novel biomarkers of exposure to oxidative stress-inducing pesticides in freshwater fish Channa punctata (Bloch). Environ Toxicol Pharmacol 20:112-117 doi:10.1016/j.etap.2004. 11.002

Raikar SV, Iima M, Fujita Y (2001) Effect of temperature, salinity and light intensity on the growth of Gracilaria from Japan, Malaysia and India. Indian J Mar Sci 30:98-104

Rebolloso Fuentes MM, Acién Fernández GG, Sanchéz Peréz JA, Guil Guerrero JL (2000) Biomass nutrient profiles of the microalga Porphyridium cruentum. Food Chem 70:345-353

Roberts DA, Poore AG, Johnston EL (2006) Ecological consequences of copper contamination in macroalgae: effects on epifauna and associated herbivores. Environ Toxicol Chem 25:2470-2479

Roe JH (1955) The determination of sugar in blood and spinal fluid with anthrone reagent. J Biol Chem 212:335-343

Sanchéz-Rodriguez I, Huerta-Diaz MA, Choumiline E, Holguín-Quinoñes O, Zertuche-Gonzélez JA (2001) Elemental concentrations in different species of seaweeds from Loreto Bay, Baja California Sur, Mexico: implications for the geochemical control of metals in algal tissue. Environ Pollut 114:145-160

Voets J, Talloen W, de Tender T, van Dongen S, Covaci A, Blust R, Bervoets 1 (2006) Microcontaminant accumulation, physiological condition and bilateral asymmetry in zebra mussels (Dreissena polymorpha) from clean and contaminated surface waters. Aquat Toxicol 79:213-225

Editorial responsibility: Hans Heinrich Janssen, Oldendorf/Luhe, Germany
Wan L, Wang N, Li Q, Sun B and others (2008) Distribution of dissolved metals in seawater of Jinzhou Bay, China. Environ Toxicol Chem 27:43-48

> Wang WX, Dei RCH (1999) Kinetic measurements of metal accumulation in two marine macroalgae. Mar Biol 135: $11-23$

> Wang MJ, Wang WX (2008) Temperature-dependent sensitivity of a marine diatom to cadmium stress explained by subcellular distribution and thiol synthesis. Environ Sci Technol 42:8603-8608

> Wang Y, Yu QY, Tang XX, Wang LL (2009) Calcium pretreatment increases thermotolerance of Laminaria japonica sporophytes. Prog Nat Sci 19:435-442

- Weinberger F, Buchholz B, Karez R, Wahl M (2008) The invasive red alga Gracilaria vermiculophylla in the Baltic Sea: adaptation to brackish water may compensate for light limitation. Aquat Biol 3:251-264

Wu CY, Li RZ, Lin GH, Wen ZC (1994) Study on the optimum environmental parameters for the growth of Gracilaria tenuistipitata var. liui in pond culture. Oceanol Limnol Sin 25:60-67

> Xia JR, Li YJ, Lu J, Chen B (2004) Effects of copper and cadmium on growth, photosynthesis, and pigment content in Gracilaria lemaneiformis. Bull Environ Contam Toxicol 73: 979-986

Yang F, Xiao XW, Zhang S, Korpelainen H, Li CY (2009) Salt stress responses in Populus cathayana Rehder. Plant Sci 176:669-677

Zemke-White WL, Ohno M (1999) World seaweed utilization: an end-of-century summary. J Appl Phycol 11:369-376

Submitted: April 14, 2010; Accepted: September 6, 2010 Proofs received from author(s): October 25, 2010 